\title{
Preferensi Konsumen Dalam Memilih Bank BRI dan Bank BCA Di Manado Berdasarkan Kualitas Pelayanan
}

\author{
Andro Tumbelaka \\ Paulus Kindangen \\ Johnny A.F Kalangi \\ Jurusan Manajemen Perusahaan, Program Studi Pengelolaan Sumberdaya Pembangunan \\ Fakultas Pascasarjana, Universitas Sam Ratulangi \\ andro.tumbelaka@gmail.com
}

\begin{abstract}
The immediate objectives of this research study is to find out which criteria are the most influential in choosing a bank and to find out which bank is preferred by customers between BRI bank and BCA bank in Manado. Quantitative research was adapted as a method in this study and used a questionnaire as a reflection of the method. The sample in this study were all customers of Bank BRI, and Bank BCA who had experience with the two banks. The questionnaire will be distributed using the purposive sampling method. The analytical method used in this study is the Analytical Hierarchy Process (AHP) where this method can rank criteria and produces weights for each evaluation criterion according to pairwise comparisons of decision makers of the criteria, so that researchers get a good picture of using the criteria.
\end{abstract}

Keywords: Consumer Preference, Service Quality, Analytical Hierarchy Process

\section{Pendahuluan}

Sektor Perbankan memegang peranan penting dalam usaha pengembangan di sektor ekonomi, dan juga berperan dalam meningkatkan pemerataan pembangunan dan hasil-hasilnya, serta pertumbuhan ekonomi dan stabilitas nasional ke arah peningkatan taraf hidup rakyat. Perkembangan jasa perbankan tumbuh begitu pesat dikarenakan perbankan berperan sangat penting bagi kelancaran kegiatan perekonomian dari suatu negara. Menurut Undang-Undang No. 10 Tahun 1998 tentang Perbankan, menyebutkan bahwa "Bank adalah badan usaha yang menghimpun dana dari masyarakat dalam bentuk simpanan dan menyalurkan kepada masyarakat dalam bentuk kredit dan/atau bentuk-bentuk lainnya dalam rangka meningkatkan taraf hidup rakyat banyak".

Seiring perkembangan pembangunan dan kinerja perekonomian Indonesia yang terus membaik juga tercermin pada perkembangan ekonomi di daerah yang tumbuh positif tak terkecuali di Propinsi Sulawesi Utara. Dengan meningkatnya perekonomian Sulawesi Utara, simpanan masyarakat yang berhasil dihimpun oleh lembaga-lembaga keuangan baik itu bank 
pemerintah maupun bank swasta tumbuh meningkat, pertumbuhan ekonomi berdampak pada pendapatan perkapita masyarakat Sulawesi Utara yang mengalami kenaikan.

Usaha jasa perbankan yang merupakan usaha jasa yang berdasarkan pada azas kepercayaan mengutamakan masalah kualitas pelayanan (service quality). Kualitas pelayanan dibangkitkan untuk menjalin ikatan yang kuat dengan perusahaan. Ikatan seperti ini dalam jangka Panjang memungkinkan perusahaan untuk memahami dengan seksama harapan pelanggan dan kebutuhan mereka, dengan demikian perusahaan tersebut dapat meningkatkan kepuasan pelanggan dimana perusahaan memaksimalkan pengalaman pelanggan yang menyenangkan, serta meminimumkan pengalaman nasabah yang kurang menyenangkan. Melalui kualitas pelayanan yang mumpuni yang disediakan oleh perusahaan maka pelanggan bisa menentukan bank mana yang akan dipercayai. Akan tetapi seringkali tetap terjadi kesenjangan antara kinerja Bank dengan harapan nasabah. Seringkali nasabah mengeluhkan atas pelayanan yang diberikan bank, nasabah mengeluh dan menilai kalau pelayanan yang dilakukan bank kurang cepat dan tanggap sekalipun bank sendiri sudah berupaya memberikan pelayanan yang cepat. Menghadapi persaingan yang ketat, menjaga atau bahkan meningkatkan kinerja perusahaan merupakan suatu tuntutan untuk dapat bertahan di industri perbankan, sehingga perancangan program peningkatan kepuasan nasabah marak dilakukan. Berbagai upaya untuk meningkatkan kualitas pelayanan dilakukan oleh bankbank di Manado seperti melakukan promosi dan menawarkan produk baru, serta memperbaiki fasilitas yang dimiliki seperti penambahan jumlah ATM, perekrutan karyawan melalui seleksi karyawan terbaik, juga fasilitas lain yang memudahkan nasabahnya. Persaingan yang ditunjukan oleh Bank milik Pemerintah dan Bank milik Swasta Nasional terlihat dari besarnya kualitas aset, penghimpunan dana pihak ketiga, dan pemberian kredit. Nasabah yang saat ini semakin kritis dan berani menyampaikan keluhan ataupun rasa ketidakpuasan saat menemui permasalahan dalam pelayanan suatu bank.

\section{Tinjauan Pustaka}

Preferensi konsumen merupakan suatu sikap konsumen terhadap satu pilihan merek produk yang terbentuk melalui evaluasi atas berbagai macam merek dalam berbagai pilihan yang tersedia. Kotler dan Keller, (2009). Sedangkan menurut Frank (2011), preferensi adalah proses meranking seluruh hal yang dapat dikonsumsi dengan 
tujuan memperoleh preferensi atas suatu produk maupun jasa.

Preferensi konsumen sangat penting dilakukan untuk membantu produsen merancang strategi pemasaran yang tepat guna memenangkan peta persaingan terhadap merek yang beredar di pasaran. Preferensi konsumen sendiri dapat membantu produsen untuk melihat apakah atribut yang ditawarkan pada produk sudah memenuhi harapan konsumen atau belum sehingga produsen pun dapat membuat produk dengan melihat pilihan atribut yang disukai oleh konsumen atau mempertahankan atribut pilihan konsumen.

Kualitas pelayanan dapat diartikan sebagai perbandingan antara pelayanan yang diharapkan konsumen dengan pelayanan yang diterimanya (Tjiptono, 2005). Kualitas pelayanan jasa digambarkan sebagai bentuk sikap, tetapi tidak sama dengan kepuasan, yang dihasilkan dari perbandingan antara harapan konsumen dengan kemampuan perusahaan. Kualitas dari sebuah pelayanan sangat tergantung pada dua variable, yaitu pelayanan yang diharapkan atas pelayanan yang didapatkan dan pengalaman yang telah dialami sebelumnya, pada saat mendapat pelayanan.

Kualitas Pelayanan adalah seberapa jauh perbedaan antara harapan dan kenyataan para pelanggan atas layanan yang mereka terima. Kualitas Pelayanan dapat diketahui dengan cara membandingkan persepsi pelanggan atas layanan yang benar-benar mereka terima dengan layanan sesungguhnya yang mereka harapkan. Kualitas pelayanan menjadi hal utama yang diperhatikan serius oleh perusahaan, yang melibatkan seluruh sumber daya yang dimiliki perusahaan (Yanuar, et al, 2017)

Menurut McDaniel, et al (2011) Lima dimensi kualitas layanan adalah:

1) Daya tanggap adalah kesediaan membantu konsumen dan memberikan layanan tepat waktu (Kotler dan Keller,2009). Beberapa indikator daya tanggap adalah selalu membantu konsumen tentang kapan layanan akan dilaksanakan, layanan tepat waktu bagi konsumen, kesediaan untuk membantu konsumen dan kesiapan untuk merespons permintaan konsumen. Pengertian lain daya tanggap adalah suatu kemauan untuk membantu dan memberikan pelayanan yang cepat dan tepat kepada konsumen melalui penyampaian informasi yang jelas, serta didukung keinginan para staf untuk membantu kesulitan para konsumen (Suryani, 2013).

2) Keandalan merupakan kemampuan perusahaan untuk memberikan pelayanan dengan baik sesuai dengan yang dijanjikan secara akurat dan 
terpercaya. Kinerja sesuai dengan harapan pelanggan yang berarti ketepatan waktu, pelayanan yang sama untuk semua pelanggan tanpa kesalahan, sikap yang simpatik, dan dengan akurasi yang tinggi (Lupiyoadi dan Hamdani, 2006).

3) Jaminan adalah pengetahuan dan kesopanan karyawan dan kemampuan mereka untuk menyampaikan kepercayaan. Karyawan yang terampil mengancam pelanggan dengan rasa hormat dan membuat pelanggan merasa bahwa mereka dapat mempercayai perusahaan untuk memberikan jaminan. Menurut Auka et al (2013) Konstruksi jaminan terdiri dari kompetensi (kepemilikan keterampilan dan pengetahuan yang diperlukan untuk melakukan layanan), kesopanan (pertimbangan untuk properti pelanggan, penampilan personil kontak publik yang bersih dan rapi), kredibilitas dan keamanan perusahaan yang meliputi hal-hal yang berhubungan dengan kepercayaan konsumen kepada perusahaan seperti, reputasi perusahaan, prestasi dan lainlain.

4) Empati adalah memberikan perhatian, tulus, dan bersifat individual atau pribadi kepada konsumen dengan berupaya memahami keinginan konsumen, dimana suatu perusahaan diharapkan memiliki suatu pengertian dan pengetahuan tentang konsumen, memahami kebutuhan konsumen secara spesifik, serta memiliki waktu pengoperasian yang nyaman bagi konsumen (Ratnasari dan Aksa,2011). Pengertian lain empati adalah kemampuan perusahaan atau para staf perusahaan dalam memberikan perhatian yang tulus secara personal para konsumen dengan berupaya memahami keinginan konsumen, yang meliputi: kemudahan untuk dihubungi, komunikasi yang baik dan memahami kebutuhan konsumen (Suryani,2013).

5) Bukti fisik adalah bukti konkret dari layanan tersebut. Bagian layanan yang nyata termasuk fasilitas fisik, kebersihan fasilitas, dan peralatan yang digunakan untuk menyediakan layanan, seperti kantor dokter, dan penampilan personel atau karyawan (McDaniel et al, 2011). Menurut Parasuraman et al (1988) Pentingnya dimensi bukti fisik ini akan menumbuhkan image penyedia jasa terutama bagi konsumen baru dalam mengevaluasi kualitas jasa. Perusahaan yang tidak memperhatikan fasilitas fisiknya akan menumbuhkan kebingungan atau bahkan merusak image perusahaan. 


\section{Metode Penelitian}

Penelitian ini menggunakan metode kuantitatif. Penelitian ini akan dilakukan di kota Manado khususnya pada area Bank yaitu Bank BRI, dan Bank BCA . Populasi dalam penelitian ini adalah orang-orang di Manado yang memiliki pengalaman dalam menggunakan layanan Bank BRI, dan Bank BCA. Sampel penelitian ini adalah semua pelanggan Bank BRI, dan Bank BCA sebanyak 50 responden yang memiliki pengalaman pada dua bank tersebut. Desain pengambilan sampel adalah purposive sampling. Metode analisis yang digunakan dalam penelitian ini adalah Analitical Hierarchy Process (AHP).

\section{Hasil Penelitian}

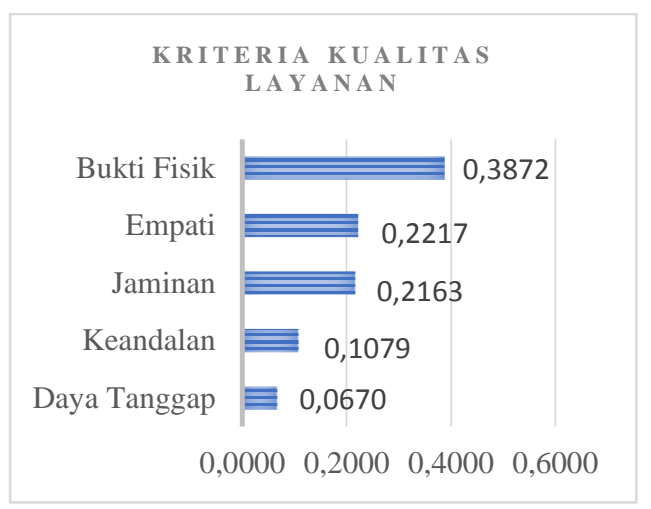

Pertama, untuk kriteria keseluruhan (daya tanggap, kehandalan, jaminan, empati, dan bukti fisik). Kriteria yang paling mempengaruhi pelanggan dalam memilih adalah 'bukti fisik'.

Bukti fisik (0.3872) adalah kriteria yang paling berpengaruh pada konsumen dalam memilih bank karena pelanggan ingin bukti konkret dalam menerima suatu layanan. Bagian layanan yang nyata termasuk fasilitas fisik seperti gedung dan ruangan front office, tersedianya tempat parkir, kebersihan, kerapian dan kenyamanan ruangan, kelengkapan peralatan komunikasi, peralatan komputer yang canggih dan seragam karyawan atau karyawati yang berpenampilan menarik akan menjadi pertimbangan bagi setiap individu untuk menentukan di bank mana dia akan menjadi pelanggan. Prasarana yang berkaitan dengan layanan pelanggan juga harus diperhatikan oleh manajemen perusahaan. Gedung yang megah dengan fasilitas pendingin (AC), alat telekomunikasi atau perabot kantor yang berkualitas, dan Iain-lain. Kemampuan sarana dan prasarana fisik dapat diandalkan akan menjadi bukti nyata dari pelayanan yang diberikan oleh suatu bank. Sebaliknya, perusahaan yang tidak memperhatikan fasilitas fisiknya akan menumbuhkan ketidaknyamanan terhadap pelanggan atau bahkan mengurangi citra perusahaan. Bukti fisik memiliki skor tertinggi dibandingkan dengan empat kriteria lainnya, dan menjadi kriteria paling penting yang disukai oleh responden. Responden adalah mereka yang telah berpengalaman pada dua bank berdasarkan persyaratan menggunakan metode AHP. Jadi dalam penelitian ini, menurut 
responden, bukti fisik menjadi faktor yang paling berpengaruh bagi pelanggan dalam memilih bank di Manado.

$$
\text { Empati (0.2217) menempati }
$$

peringkat kedua sebagai kriteria yang paling berpengaruh pada konsumen dalam memilih bank dikarenakan faktor empati memberikan perhatian yang bersifat individual atau pribadi kepada pelanggan dan berupaya untuk memahami konsumen, sehingga memberikan kemudahan dalam melakukan hubungan dengan pelanggan serta berupaya memahami keinginannya. Suatu perusahaan diharapkan memiliki pengertian dan pengetahuan tentang pelanggan, memahami kebutuhan pelanggan secara spesifik, serta memiliki waktu pelayanan bagi pelanggan. Perusahaan diharapkan pula untuk melakukan komunikasi individu agar hubungan dengan pelanggan lebih akrab. Komunikasi adalah proses untuk menyampaikan informasi kepada konsumen atau memperoleh masukan dari konsumen untuk mengetahui, memahami, dan merespon keinginan konsumen. Jadi melalui empati, pelanggan dapat memperoleh perlakuan dan pelayanan terbaik dan mendapat manfaat optimal dari produk (jasa) yang disediakan oleh perusahaan.

Di posisi ketiga yaitu Jaminan (0.2163). Jaminan juga menjadi salah satu kriteria penting bagi pelanggan untuk mengetahui kompetensi dari karyawan yang meliputi keterampilan dan pengetahuan yang dimiliki karyawan, serta kredibilitas perusahaan yang berupa hal-hal yang berhubungan dengan kepercayaan konsumen kepada perusahaan seperti, reputasi perusahaan, prestasi, kesopanan, dan sifat dapat dipercaya dari karyawan. Karyawan perusahaan diharuskan tampil kompeten, artinya memiliki pengetahuan dan keahlian di bidang masing-masing serta memberikan rasa aman dan terjamin kepada pelanggan.

Selanjutnya di peringkat keempat yaitu Keandalan (0.1079). Kemampuan pelayanan yang diberikan harus sesuai dengan apa yang dijanjikan. Karyawan harus menanggapi keluhan pelanggan dengan segera, akurat, dan memuaskan. Hai ini berarti perusahaan harus memberikan jasa pelayanannya secara tepat. Kepuasan konsumen akan menurun bila jasa yang diberikan tidak sesuai dengan apa yang dijanjikan.

Ditempat terakhir yaitu Daya Tanggap (0.0670), daya tanggap merupakan kemampuan perusahaan yang dilakukan langsung oleh karyawan untuk memberikan pelayanan dengan cepat dan tanggap. Karyawan perusahaan harus mempunyai respon atau kesigapan dalam membantu pelanggan dan memberikan 
pelayanan yang cepat meliputi kesigapan karyawan dalam melayani pelanggan, kecepatan karyawan dalam menangani transaksi, selalu siap membantu pelanggan. Meskipun berada di posisi terakhir bukan berarti daya tanggap tidak penting dalam hal kualitas layanan.

Dari hasil analisis, ada tiga kriteria teratas yang memiliki pengaruh paling besar terhadap pelanggan dalam memilih bank. Bukti fisik adalah kriteria yang paling disukai pelanggan dalam memilih bang diikuti oleh empati diperingkat kedua dan kemudian jaminan berada diperigkat ketiga. Hasil penelitian ini mendukung temuan penelitian sebelumnya oleh Marcell dan Michael (2017) yang mengatakan bahwa variable bukti fisik memiliki pengaruh yang paling dominan bagi loyalitas pelanggan pada auto bridal di Surabaya, dan sesuai dengan teoti dari Parasuraman et al (1988) yaitu Pentingnya dimensi buktifisik akan menumbuhkan image penyedia jasa terutama bagi konsumen baru dalam mengevaluasi kualitas jasa. Perusahaan yang tidak memperhatikan fasilitas fisiknya akan menumbuhkan kebingungan atau bahkan menurunkan image perusahaan. Penelitian ini juga sejalan dengan penelitian sebelumnya dari Putri dan Nurcaya (2011) yang mengemukakan hasil dimana variabel jaminan memiliki pengaruh paling dominan diantara variabel lainnya terhadap kepuasan pelanggan, namun bertolak belakang atau tidak sejalan dengan penelitian dari Sriwidodo dan Indriastuti (2010) yaitu di antara kelima dimensi kualitas layanan di PT. Bank Jateng Cabang Karanganyar yang memberikan pengaruh besar terhadap kepuasan nasabah adalah dimensi daya tanggap yang menunjukkan bahwa evaluasi nasabah mengenai ketanggapan merupakan faktor yang amat penting dalam membentuk kepuasan, pada kenyataanya di penelitian ini daya tanggap berada pada peringkat terakhir.

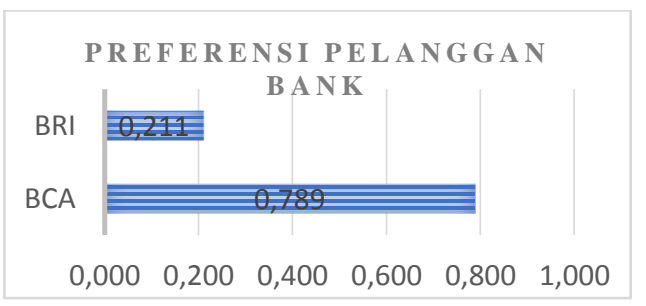

Berdasarkan data keseluruhan, pelanggan cenderung memilih Bank BCA sebagai bank yang paling disukai di Manado dibandingkan dengan alternatif lain yaitu Bank BRI. Hasil ini sudah ditunjukkan pada table diatas, yang mana menunjukkan bahwa ketika orang ingin menjadi pelanggan atau nasabah, mereka lebih suka memilih Bank BCA sebagai Bank yang paling disukai di bandingkan Bank BRI.

\section{Kesimpulan}

Berdasarkan hasil analisis yang telah diuraikan pada bab sebelumnya, dalam 
penelitian ini dapat disimpulkan hal-hal berikut ini:

1. Berdasarkan lima kriteria (daya tanggap, kehandalan, jaminan, empati, dan bukti fisik) Bukti fisik memiliki skor tertinggi dibandingkan dengan empat kriteria lainnya, dan menjadi kriteria yang di anggap paling penting oleh responden. Empati di peringkat kedua sebagai kriteria yang paling berpengaruh pada konsumen dalam memilih bank, diikuti jaminan dan keandalan yang berada di posisi tiga dan empat, serta posisi terakhir ditempati oleh kriteria daya tanggap.

2. Bank BCA dipilih sebagai bank yang paling disukai di Manado dibandingkan dengan Bank BRI.

\section{Saran}

1. Bukti fisik memiliki peran penting dalam memilih bank. Bukti fisik menjadi kriteria paling dominan yang dipertimbangkan oleh responden yang mempengaruhi seleksi mereka dalam memilih atau menentukan kualitas layanan pada suatu bank. Oleh karena itu, setiap bank khususnya di Manado harus memperhatikan faktor ini. Para pelanggan ingin bukti konkret dalam menerima suatu layanan. Pelangan menilai sesuatu yang akan langsung dirasakan saat memasuki sebuah bank.
Layanan yang nyata seperti kebersihan, kerapian dan kenyamanan ruangan, karyawan/ti yang berpenampilan menarik akan menjadi pertimbangan bagi setiap individu untuk menentukan bank mana yang akan dipilih. Bukti fisik adalah bagian atau faktor penting bagi bank untuk mempertahankan pelanggan mereka.

2. Bank BRI harus meningkatkan kinerja perusahaan dalam hal kualitas layanan karena Bank BCA mendominasi kinerja terbaik di semua kriteria yang membuta Bank ini mampu menarik banyak pelanggan untuk menjadi nasabah.

3. Ketika pelanggan ingin membuat keputusan untuk memilih bank yang paling disukai, mereka akan memberikan perhatian lebih pada tiga kriteria yang paling berpengaruh, yaitu bukti fisik, empati dan jaminan dari bank yang akan dipercayakan dalam menjadi nasabah.

\section{Daftar Pustaka}

Auka D O, Bosire J N, and Matern V (2013) Perceived Service Quality and Customer Loyalty In Retail Banking In Kenya. British Journal of Marketing Study. Vol.1, No.3, pp. 32-61.

Frank R H. (2011). Microeconomics and Behavior. Eighth edition, Mc.Graw. Hill International Edition 
Kotler P and Armstrong G(2009), Principles of Marketing 13th Edition. Pearson Education, Inc., Upper Saddle River, New Jersey, 07458.

Lupiyoadi, Hamdani. 2006. Manajemen Pemasaran Jasa, Edisi Kedua. Jakarta: Salemba Empat.

Marcell dan Adiwijaya M (2017) Pengaruh Dimensi Kualitas Layanan terhadap Loyalitas Pelanggan di Auto Bridal Surabaya. Jurnal AGORA Vol. 5, No. 1, (2017)

McDaniel C, Lamb C.W, Hair J.F. (2011) Introduction to marketing 11th edition. South-Western, Cengage Learning

Parasuraman A, Zeithalm V, dan Berry L, (1988). SERVQUAL: A Multiple item Scale for Measuring Consumer Perceptions of Service Quality, Journal of Retailing.

Putri K I N S dan I Nyoman Nurcaya I N (2011) Pengaruh Dimensi Kualitas Pelayanan Jasa terhadap Kepuasan Pelanggan D\&I Skin Centre Denpasar. Jurnal Fakultas Ekonomi Universitas Udayana, (Unud) Bali, Indonesia.

Ratnasari R T dan Mastuti Aksa. 2011. Manajemen Pemasaran Jasa. Ghalia Indonesia. Bogor.

Sriwidodo U dan Indriastuti R T (2010) Pengaruh Dimensi Kualitas Pelayanan Jasa terhadap Kepuasan Nasabah. Jurnal Ekonomi dan Kewirausahaan Vol. 10, No. 2, Oktober $2010: 164$ 173

Suryani, T. 2013. Perilaku Konsumen di Era Internet : Implikasinya pada Strategi Pemasaran. Edisi Pertama. Graha Ilmu. Yogyakarta.
Tjiptono, Fandi dan Gregorius Chandra. "Service Quality Satisfaction". Penerbit Andi. Yogyakarta. 2005 